\title{
BAHAN AJAR BERBASIS KEARIFAN LOKAL DAN BUDAYA UNTUK MENINGKATKAN KETERAMPILAN MENULIS DESKRIPSI
}

\author{
Nana Sutarna, Ahmad Fajri Lutfi \\ Program Studi PGSD STKIP Muhammadiyah Kuningan \\ Jl. Moertasiah Soepomo No 28B Cigugur - Kuningan, 45511 \\ Correspondence E-mail: nana@upmk.ac.id
}

\begin{abstract}
This study aims to describe the effect of teaching materials based on local wisdom and culture on the writing skills of elementary school students. This type of research is the development of research (Research Development) using a model developed by Borg and Gall. The development of teaching materials starts from the preliminary study stage, planning, product design, product design validation, product testing and final products. The research instrument used consisted of validation sheets, sheets, student needs analysis questionnaires, and cognitive tests. The subjects of the research trials were Grade IV students of SDN 1 Cengal, SDN 2 Cengal and $\mathrm{SDN}_{3}$ Cengal, Japara District, Kuningan Regency. The results showed that there was an increase in the skills of writing descriptions of students who used teaching materials based on local wisdom and culture compared to students who used conventional learning. The difference in this increase can be seen in the results of the gain test of students' description writing skills in the experimental class showing an N-gain of 0.46 . Then the N-gain in the experimental class is included in the moderate criteria. While the results of the gain test for students' description writing skills in the control class obtained an $\mathrm{N}$ gain of 0.28. Then the N-gain in the control class is included in the low criteria.
\end{abstract}

Keywords:

teaching materials, local wisdom, culture, writing skills

\begin{abstract}
Abstrak
Penelitian ini bertujuan untuk mendeskripsikan pengaruh bahan ajar berbasis kearifan lokal dan budaya terhadap keterampilan menulis deskripsi siswa sekolah dasar. Jenis penelitian ini adalah penelitian pengembangan (Development Research) dengan menggunakan model yang dikembangkan oleh Borg and Gall. Pengembangan bahan ajar dimulai dari tahap studi pendahuluan, perencanaan, desain produk, validasi desain produk, uji coba produk dan produk akhir. Instrumen penelitian yang digunakan terdiri dari lembar validasi, lembar, angket analisis kebutuhan siswa, dan tes kognitif. Subjek uji coba penelitian yaitu siswa Kelas IV SDN 1 Cengal, SDN 2 Cengal dan SDN 3 Cengal Kecamatan Japara Kabupaten Kuningan. Hasil penelitian menunjukkan bahwa terdapat peningkatan keterampilan menulis deskripsi siswa yang menggunakan bahan ajar berbasis kearifan lokal dan budaya dibandingkan dengan siswa yang menggunakan pembelajaran konvensional. Perbedaan peningkatan ini dapat dilihat pada hasil uji gain keterampilan menulis deskripsi siswa pada kelas eksperimen menunjukkan N-gain sebesar o,46. Maka Ngain pada kelas eksperimen termasuk ke dalam kriteria sedang. Sedangkan hasil uji gain keterampilan menulis deskripsi siswa pada kelas kontrol diperoleh $\mathrm{N}$-gain sebesar 0,28. Maka N-gain pada kelas kontrol termasuk ke dalam kriteria rendah.
\end{abstract}

\section{Kata Kunci:}

bahan ajar, kearifan lokal, budaya, keterampilan menulis deskripsi 


\section{A. PENDAHULUAN}

Dunia sedang menghadapi era revolusi Peraturan Menteri Pendidikan Nasional Republik Indonesia Nomor 64 Tahun 2013 tentang Standar Isi menjelaskan bahwa bahasa memiliki sentral dalam perkembangan intelektual, sosial dan emosional siswa dan merupakan penunjang keberhasilan dalam mempelajari semua bidang studi. Pembelajaran bahasa diharapkan membantu siswa mengenal dirinya, budayanya dan budaya orang lain, mengemukakan gagasan dan perasaan, berpartisipasi dalam masyarakat yang menggunakan bahasa tersebut, dan menemukan serta menggunakan kemampuan analisis dan imaginatif yang ada dalam dirinya.

Iskandarwassid dan Sunendar (2011: 248) menjelaskan bahwa menulis adalah keterampilan berbahasa yang paling akhir dikuasai setelah keterampilan mendengarkan, berbicara, dan membaca. Keterampilan menulis membutuhkan kemampuan berbahasa yang bersifat aktif dan produktif. Sokolik mengemukakan bahwa 'writing is a combination of process and product'. Sedangkan Olson berpendapat bahwa 'the concept that writing is a process is very useful to young writers' (Linse, 2005: 98). Berdasarkan dua pendapat tersebut dapat disimpulkan bahwa menulis adalah perpaduan proses dan hasil yang bermakna bagi penulis.

Graves banyak melakukan penelitian tentang pembelajaran menulis menyampaikan banyak manfaat menulis yaitu menulis mengembangkan kecerdasan, menulis mengembangkan daya inisiatif dan kreatif, menulis mendorong kebiasaan serta memupuk kemampuan dalam menemukan, mengumpulkan, dan mengorganisasikan informasi, dan menulis menumbuhkan kepercayaan diri dan keberanian (Yunus,
2013). Meskipun demikian, pentingnya keterampilan menulis di sekolah dasar belum diimbangi dengan hasil menulis yang baik. Alfianto (2008) menyatakan bahwa minat siswa baik yang menyangkut minat menulis, maupun minat untuk mengikuti pelajaran Bahasa Indonesia semakin tampak menurun. Hal ini disebabkan oleh beberapa faktor, yaitu pelajaran bahasa Indonesia dianggap pelajaran yang membosankan, pembelajaran hanya bersifat monoton kurang variasi karena hanya berupa pemberian tugas mengarang/ menulis, pelajaran menulis adalah pelajaran yang dianggap sulit oleh siswa, dan pengajaran bahasa Indonesia terlalu kaku dan beracuan untuk mengejar materi saja.

Faktor lain penyebab rendahnya keterampilan menulis siswa menurut Abidin (2013: 191) adalah kecenderungan guru yang lebih mengutamakan tata bahasa dalam menulis dibanding dengan bagaimana mengemukakan gagasan dalam menulis. Hal ini menyebabkan siswa menjadi mampu bertata bahasa dengan baik namun isi tulisan kurang berbobot. Oleh karena itu perlu adanya peningkatan kualitas pembelajaran dengan melakukan berbagai cara. Salah satunya dengan mengembangkan bahan ajar dan pemilihan model pembelajaran yang sesuai dengan tahapan pembelajaran menulis. Tujuan dari pengembangan bahan ajar adalah agar bahan ajar yang digunakan oleh siswa sesuai dengan kebutuhan dan karakteristik siswa.

Implementasi pembelajaran tematik seharusnya dikaitkan dengan lingkungan siswa yang mengarah kepada tercapainya pengetahuan maupun pengenalan lingkungan 
sekitar siswa. Dalam lampiran IV Permendikbud Nomor 81A tahun 2013 ditegaskan bahwa pembelajaran di sekolah tingkat dasar dikembangkan secara tematik, keterpaduan lintas mata pelajaran untuk mengembangkan sikap, keterampilan, dan pengetahuan serta mengapresiasi keragaman budaya lokal (Shufa, 2018).

Salah satu cara pengembangan bahan ajar yang sesuai dengan kebutuhan dan karakteristik siswa adalah dengan menambahkan kearifan lokal. Kearifan lokal dapat diinternalisasikan dalam pendidikan karena memiliki banyak kelebihan. Kelebihan tersebut antara lain kearifan lokal dapat menjadi sarana pembelajaran bagi setiap manusia untuk menjadi orang yang cerdas, pandai, dan bijaksana; kearifan lokal memiliki nilainilai positif untuk mentransformasikan kepada siswa guna membentuk kepribadian positif (Mulyasa, 2012:2). Hal tersebut diperkuat dengan pernyataan dari Vygotsky (Kozulin et al., 2003) yang memaparkan, "Learning awakens a variety of internal developmental processes that are able to operate only when the child is interacting with people in his environment and in cooperation with people". Hal ini menunjukkan bagaimana pentingnya interaksi sosial dari siswa baik di lingkungan sekolah maupun di lingkungan tempat tinggalnya guna membangun kerjasama sebagai suatu proses pengembangan diri.

Hal-hal di atas juga sesuai dengan prinsip pembelajaran kurikulum 2013 dalam Permendikbud Nomor 103 Tahun 2014 yang salah satunya adalah pengakuan atas perbedaan individual dan latar belakang budaya siswa.

Kebutuhan mengenai penggunaan bahan ajar menjadi sesuatu hal yang penting. Sesuai dengan pendapat yang disampaikan Perwitasari (2018) bahwa dalam penerapan pembelajaran tematik di sekolah dasar menuntut tersedianya bahan ajar yang memadai dan dapat digunakan untuk memenuhi kebutuhan pembelajaran yang terintegrasi antar satu mata pelajaran dengan pelajaran lainnya, bahkan dengan kehidupan siswa sehari-hari. Bahan ajar sebagai sumber pendukung juga dijelaskan oleh Alfieri, Brooks, \& Aldrich (2009) yang memaparkan, "Perhaps similar reading support tools need to be developed for other texts as well so that students can come to view textbooks as helpful resources within their environments that they are able to interact with in meaningful ways to reach objectives."

Yasintus Tinja dalam penelitiannya (2017) mengatakan bahwa buku/bahan ajar yang dikembangkan harus dapat mendukung proses pembelajaran dan menampilkan keutuhan kompetensi yang akan dikuasai oleh peserta didik dalam kegiatan pembelajaran, sehingga peserta didik dapat menguasai suatu kompetensi secara utuh. Sedangkan langkah-langkah yang harus ditempuh dalam penyusunan bahan ajar adalah studi pendahuluan, perencanaan,desain produk, validasi desain produk, uji coba produk dan penyempurnaan produk akhir (Wibowo, 2017).

Hal yang perlu diperhatikan dalam merancang pembelajaran tematik adalah (1) memilih tema, (2) mengorganisasi tema, (3) mengumpulkan bahan dan sumber daya, (4) merancang kegiatan dan proyek, dan (5) menerapkan unit. Hal ini sesuai dengan pendapat Meinbach, Rothelin \& Fredericks (2005: 9) yang menyebutkan, "As you might expect, thematic teaching requires some 
planning and organization in order to make it successful. our own experiences as well as those of teachers with whom we have talked around the country, have indicated that there are five primary areas to consider in designing an effective and successful thematic unit. these include : (a) selecting the theme, (b) organizing the theme, (c) gathering material and resources, (d) designing activities and projects, (e) implementing the unit".

Berdasar pada pemaparan di atas maka peneliti bermaksud meningkatkan keterampilan menulis deskripsi siswa dengan menggunakan bahan ajar berbasis kearifan lokal dan budaya di lingkungan Kecamatan Japara Kabupaten Kuningan.

\section{B. METODE PENELITIAN}

Tujuan dari penelitian ini adalah menghasilkan bahan ajar yang teruji keefektifannya untuk diterapkan pada proses pembelajaran di sekolah dasar. Pengembangan produk bahan ajar berbasis kearifan lokal dan budaya didasarkan pada modifikasi dari prosedur Borg \& Gall (Sugiyono, 2010). Adapun langkah-langkah dari model penelitian pengembangan adalah sebagai berikut:

1. Studi Pendahuluan

Penelitian ini berangkat dari adanya potensi masalah atau masalah. Semua masalah yang muncul diidentifikasi. Pada tahap ini juga dilakukan studi literatur dan pengumpulan informasi.

\section{Perencanaan}

Tahap perencanaan terdiri dari memilih desain berdasarkan analisis kebutuhan sehingga produk yang akan dihasilkan benar-benar sesuai dan dibutuhkan dalam pembelajaran. Kemudian dilanjutkan dengan menyusun draft bahan ajar dan membuat instrumen kelayakan produk.

\section{Desain Produk}

Pada tahap ini membuat desain produk bahan ajar berbasis kearifan lokal dan budaya.

4. Validasi Desain Produk

Berisi tinjauan kepada ahli materi/isi dan ahli bahan ajar kemudian dilanjutkan dengan proses revisi produk awal.

5. Uji Coba Produk

Uji Coba produk dilakukan untuk mengetahui kualitas dan keefektifan produk yang telah dibuat sehingga dapat diketahui hal apa saja yang harus diperbaiki/disempurnakan.

6. Produk Akhir

Hasil dari rangkaian proses pembuatan produk.

Desain produk yang telah dibuat yakni berupa bahan ajar berbasis kearifan lokal dan budaya harus diujicobakan penggunaanya pada kelompok terbatas dengan tujuan mendapatkan informasi apakah produk bahan ajar yang dibuat tersebut lebih efektif dan efisien dibandingkan dengan bahan ajar yang telah ada sebelumnya.

Untuk mencapai hal tersebut maka digunakan metode penelitian eksperimen kuasi (Quasi Experimental Design) dengan the nonrandomized control group, pretest-posttest. Creswell (2012, hlm. 307) mengemukakan bahwa dalam sebuah penelitian eksperimen, peneliti menguji sebuah ide atau gagasan (baik praktek maupun prosedur) untuk menentukan apakah hal yang diujikan tersebut mempengaruhi hasil atau variabel terikat.

Ary dkk (2010:316) menyebut bahwa the nonrandomized control group, pretest-posttest adalah salah satu desain yang paling banyak 
digunakan dalam metode penelitian eksperimen kuasi dalam pendidikan. Peneliti dalam desain nonrandomized control group, pretest-posttest menentukan kelompok eksperimen (O1) dan kelompok kontrol ( $\left.\mathrm{O}_{2}\right)$, melakukan prates untuk kedua kelompok dengan maksud untuk mengetahui homogenitas dan normalitas kedua kelompok, melakukan perlakuan eksperimen (X) yang dalam penelitian ini adalah bahan ajar berbasis kearifan lokal dan budaya hanya dengan kelompok eksperimen (O1), dan kemudian melakukan pascates untuk mengukur perbedaan antara dua kelompok. Desain penelitian digambarkan dalam tabel sebagai berikut.

Tabel 1 Desain Kuasi Eksperimen

\begin{tabular}{|c|c|c|c|}
\hline $\begin{array}{c}\text { Kelomp } \\
\text { ok }\end{array}$ & Prates & $\begin{array}{c}\text { Variabel } \\
\text { bebas }\end{array}$ & $\begin{array}{c}\text { Pasca } \\
\text { tes }\end{array}$ \\
\hline $\begin{array}{c}\text { Eksperim } \\
\text { en }\end{array}$ & $\mathrm{O}_{1}$ & $\mathrm{X}_{1}$ & $\mathrm{O}_{2}$ \\
\hline Kontrol & $\mathrm{O}_{3}$ & $\mathrm{X}_{2}$ & $\mathrm{O}_{4}$ \\
\hline
\end{tabular}

(diadaptasi dari Ary, 2010)

Keterangan:

$\mathrm{O}_{1}$ : Tes awal pada kelompok eksperimen

$\mathrm{O}_{2}$ : Tes akhir pada kelompok eksperimen

$\mathrm{O}_{3}$ : Tes awal pada kelompok kontrol

$\mathrm{O}_{4}$ : Tes akhir pada kelompok kontrol

$\mathrm{X}_{1}$ : Pemberian perlakukan, bahan ajar berbasis kearifan lokal dan budaya

$\mathrm{X}_{2}$ :Pemberian perlakuan dengan metode konvensional

Alur dari desain penelitian dapat dilihat pada gambar di bawah ini.

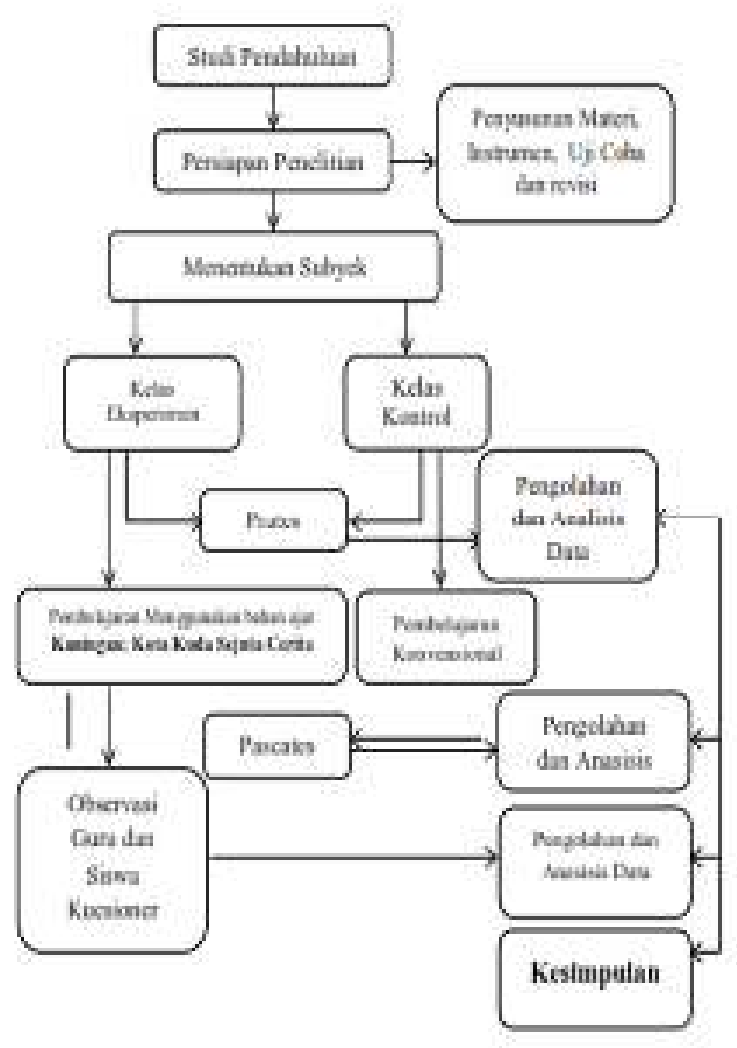

Gambar 1. Alur Penelitian

Pengambilan sampel pada penelitian ini menggunakan teknik purposive sampling. subjek penelitian ini terdiri dari tiga sekolah dasar yakni SDN 3 Cengal (sebagai kelas eksperimen dengan jumlah 35 siswa), SDN 2 Cengal (sebagai kelas kontrol dengan jumlah 37 siswa) dan SDN 1 Cengal (sebagai kelas uji coba produk berjumlah 22 siswa).

Instrumen dalam penelitian ini dibedakan menjadi instrumen pembelajaran dan instrumen pengumpul data. Instrumen pembelajaran terdiri dari bahan ajar yang dikembangkan berbasis kearifan lokal dan budaya berupa buku bahan ajar siswa. Sedangkan instrumen pengumpul data berupa lembar observasi kegiatan guru dan siswa, lembar wawancara, dan lembar tes.

Berdasarkan data yang diperoleh dalam penelitian ini yakni data 
kualitatif dan kuantitatif maka teknik yang akan digunakan untuk menganalisis data kualitatif adalah analisis secara deskriptif. Analisis deskriptif ini digunakan untuk mengetahui dan memperoleh gambaran mengenai efektivitas bahan ajar berbasis kearifan lokal dan budaya.

Sementara itu, teknik analisis data kuantitatif digunakan untuk menjawab hipotesis penelitian yang berkaitan dengan perbedaan kemampuan antara pembelajaran yang menggunakan bahan ajar berbasis kearifan lokal dan budaya dibandingkan dengan pembelajaran konvensional. Tahapan analisis data kuantitatif akan menggunakan metode statistik yaitu uji beda $(\mathrm{t})$ dengan bantuan SPSS versi 20.

Tahapan analisis data kuantitatif dengan menggunakan statistik dilakukan dengan beberapa tahapan. Tahapantahapan tersebut adalah (1) analisis data deskriptif, (2) analisis uji normalitas dan homogenitas, (3) analisis uji beda dengan menggunakan uji t.

Langkah akhir dari pengolahan data, yaitu data n-gain yang berfungsi untuk mengetahui mutu peningkatan keterampilan menulis deskripsi menggunakan bahan ajar berbasis kearifan lokal dan budaya.

\section{HASIL DAN PEMBAHASAN}

Tahapan pelaksanaan penelitian diawali dengan pengembangan produk bahan ajar berbasis berbasis kearifan lokal dan budaya, selanjutnya produk bahan ajar diuji keefektifannya untuk meningkatkan keterampilan menulis deskripsi siswa dengan metode kuasi eksperimen pada kelas eksperimen dan kelas kontrol.

\section{Pengembangan Produk Bahan Ajar}

Pengembangan produk bahan ajar berbasis kearifan lokal dan budaya didasarkan pada modifikasi dari prosedur Borg \& Gall dengan tahapan (1) studi pendahuluan, (2) perencanaan, (3) desain produk, (4) validasi produk, (5) uji coba produk, dan (6) produk akhir.

Pertimbangan yang mendasari penggunaan model pengembangan Borg \& Gall yaitu (1) model ini diawali dengan analisis kebutuhan. Analisis kebutuhan pada penelitian ini menggunakan siswa. Diharapkan produk yang dihasilkan adalah produk yang sesuai dengan kebutuhan siswa sebagai pengguna produk; dan (2) model pengembangan ini memiliki tahapan-tahapan yang rinci dan sesuai untuk mengembangkan suatu produk tertentu serta dapat menjawab masalah-masalah dalam pembelajaran. 


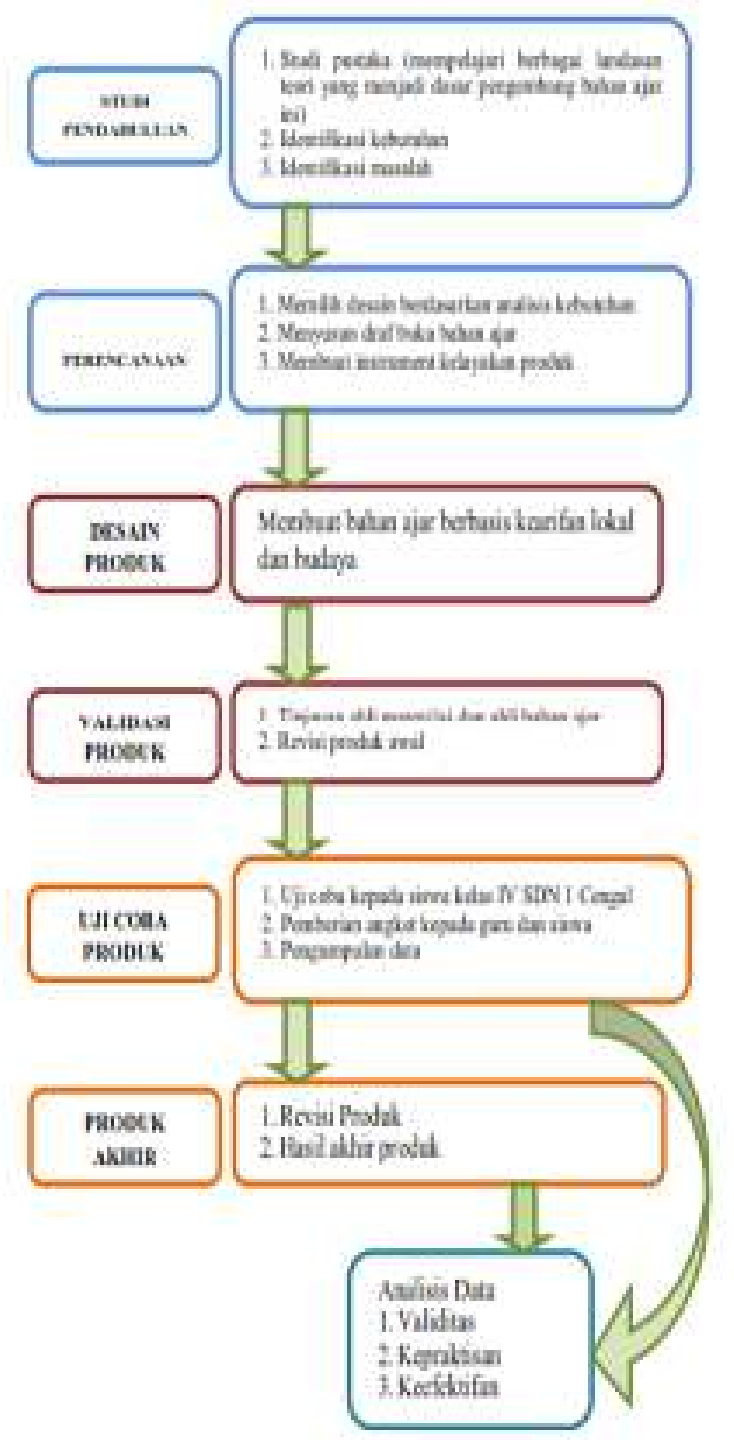

Gambar 2 Prosedur Penelitian

Pengembangan (Diadaptasi dari

Sugiyono (2010: 434)

Hasil Penelitian dan pengembangan berupa produk bahan ajar berbasis kearifan lokal dan budaya untuk siswa yang telah valid dan praktis digunakan. Hasil uji validasi ahli yaitu 90,20\% dengan kategori sangat valid. Selain validasi ahli, peneliti juga melakukan uji keterbacaan bahan ajar yang dilakukan pada siswa kelas IV SDN 1 Cengal Kuningan. Pada tes keterbacaan ini terdapat 15 kata yang dihilangkan dan harus dilengkapi oleh tiap masing-masing siswa. Hasil analisis bahan ajar pada penelitian menunjukkan bahwa keterbacaan pada buku ajar ini mudah dipahami dengan rata-rata nilai siswa adalah 89. Hasil uji kepraktisan respons siswa terhadap bahan ajar sangat praktis dengan persentase $86,89 \%$. Contoh produk bahan ajar berbasis kearifan lokal dan budaya, Kuningan: Kota Kuda

Sejuta Cerita pada Gambar 3.

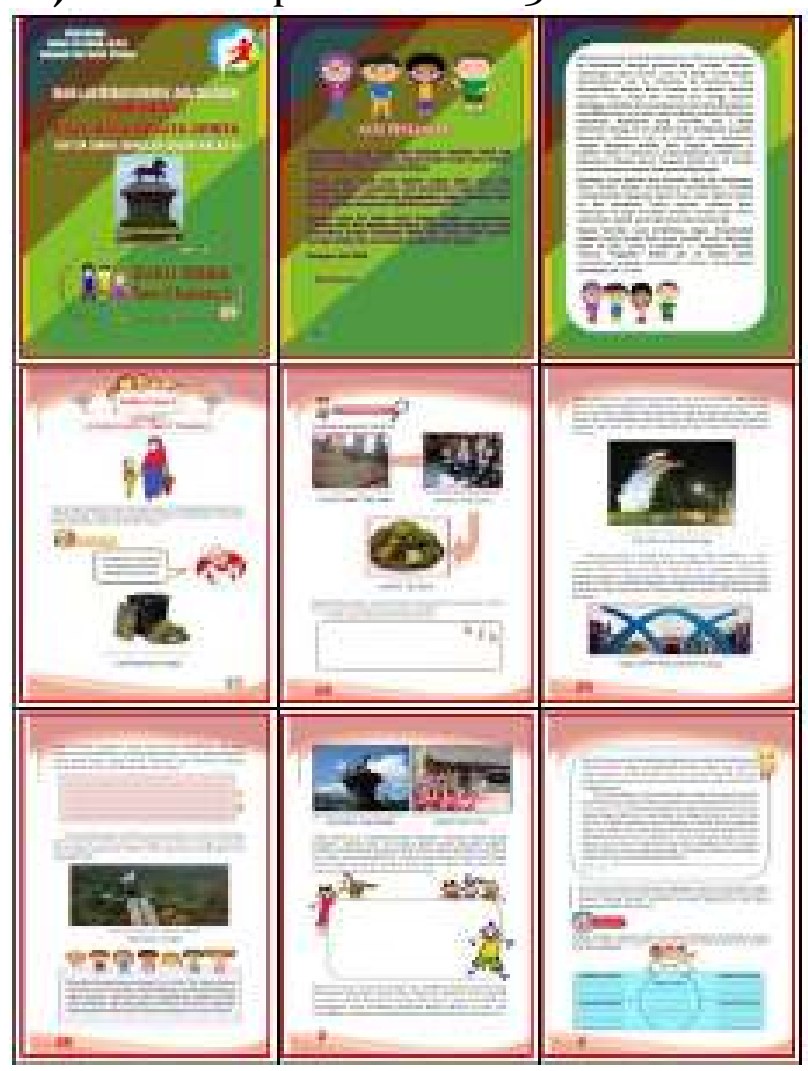

Gambar 3. Contoh Isi Produk Akhir Bahan Ajar Buku Siswa

(Sumber: Dokumentasi Peneliti, 2020)

\section{Pelaksanaan Penelitian}

Pelaksanaan penelitian dilakukan dalam enam kali pertemuan pembelajaran baik pada kelas kontrol maupun kelas eksperimen. Materi dan tahapan kegiatan dimodifikasi dengan menggunakan produk bahan ajar berbasis kearifan lokal dan budaya, Kuningan: Kota Kuda Sejuta Cerita. Setiap pertemuan dilaksanakan dalam satu hari kegiatan pembelajaran dan mencakup seluruh mata pelajaran sesuai jadwal pembelajaran di sekolah. 
Produk bahan ajar buku siswa hanya digunakan pada kelas eksperimen, sementara kelas kontrol menggunakan buku guru dan buku siswa yang telah ada sebelumnya di sekolah. Tahapan pembelajaran mencakup pra kegiatan, kegiatan inti dan kegiatan akhir.

\section{Analisis Data dan Pembahasan}

Dalam penelitian ini, untuk mengetahui keterampilan menulis deskripsi siswa dilakukan dengan memberikan tes kepada siswa pada kedua kelas. Data tersebut berupa skor pretes dan skor pascates dari kelas eksperimen dan kelas kontrol. Data hasil prates dan pascates keterampilan menulis deskripsi siswa tersebut selengkapnya dapat dilihat pada tabel berikut ini.

Tabel 2. Deskripsi Data Hasil Perhitungan

SPSS Keterampilan Menulis Deskripsi

\begin{tabular}{|l|r|r|r|r|}
\hline & $\begin{array}{c}\text { Prates_Eks } \\
\text { perimen }\end{array}$ & $\begin{array}{c}\text { Pascates_Eks } \\
\text { perimen }\end{array}$ & $\begin{array}{c}\text { Prates_K } \\
\text { ontrol }\end{array}$ & $\begin{array}{r}\text { Pascates } \\
\text { Kontrol }\end{array}$ \\
\hline N Valid & 35 & 35 & 37 & 37 \\
Missing & 0 & 0 & 0 & 0 \\
Mean & 52,5714 & 75,7143 & 46,7568 & 67,0270 \\
Median & 50,0000 & 80,0000 & 50,0000 & 70,0000 \\
Std. Deviation & 15,40490 & 11,70362 & 17,16813 & 14,31100 \\
Variance & 237,311 & 136,975 & 294,745 & 204,805 \\
Range & 80,00 & 50,00 & 60,00 & 80,00 \\
Minimum & 10,00 & 50,00 & 20,00 & 20,00 \\
Maximum & 90,00 & 100,00 & 80,00 & 100,00 \\
Sum & 1840,00 & 2650,00 & 1730,00 & 2480,00 \\
\hline
\end{tabular}

Nilai pretest kelompok eksperimen yang belum dilakukan perlakuan atau prates ditetapkan sebagai nilai awal dengan rata-rata 52,57 dan setelah dilakukan metode eksperimen diperoleh rata-rata pascates 75,71 .

Pada kelas kontrol sebelum diberikan perlakuan, siswa juga terlebih dahulu diberikan prates untuk mengetahui kemampuan awal siswa. Penilaian dilakukan dengan menggunakan IBM SPSS Statistics 20. Setelah diketahui kemampuan awal siswa, selanjutnya siswa kelas kontrol diajarkan dengan menggunakan pembelajaran konvensional. Pada pertemuan terakhir, siswa diberikan pasca tes untuk mengetahui keterampilan menulis deskripsi siswa. Nilai prates pada kelompok kontrol dengan rata-rata 46,75 dan setelah diberikan perlakuan yaitu metode konvensional maka nilai pascastes pada kelompok kontrol 67,02 .

Perbedaan nilai prates dan pascastes di kelas eksperimen memiliki selisih 23,14 sedangkan perbedaan nilai prates dan pascastes di kelas kontrol memiliki selisih 20,27. Dengan perbedaan besaran selisih antara kelas eksperimen dan kelas kontrol yang didapat, bahwa peningkatan keterampilan menulis deskripsi di kelas eksperimen lebih baik daripada kelas kontrol.

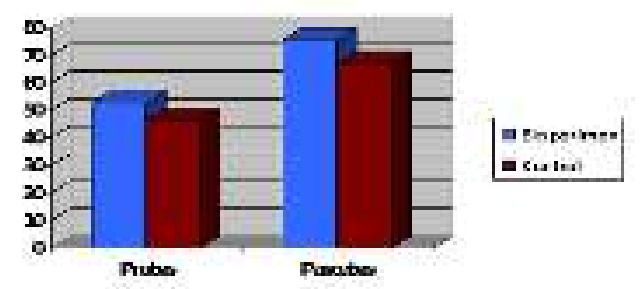

Gambar 4. Hasil Prates dan Pascates Keterampilan Menulis Deskripsi pada Kelas Eksperimen dan Kelas Kontrol

Untuk melihat hasil prates keterampilan menulis deskripsi antara kelas eksperimen dengan kontrol secara individu dapat dilihat pada grafik berikut ini: 


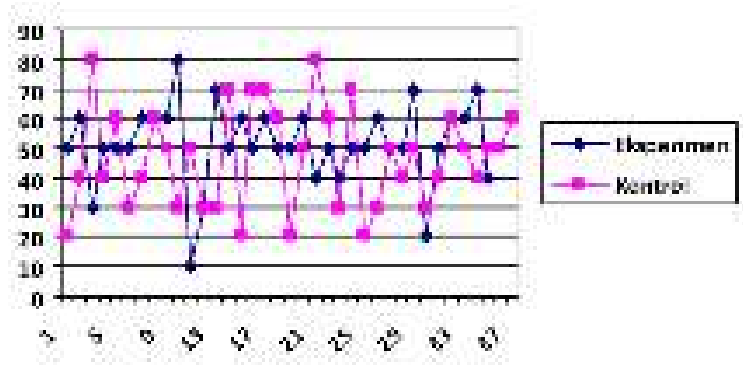

Gambar 5. Hasil Prates keterampilan menulis deskripsi siswa pada Kelas Eksperimen dan Kelas Kontrol secara individu

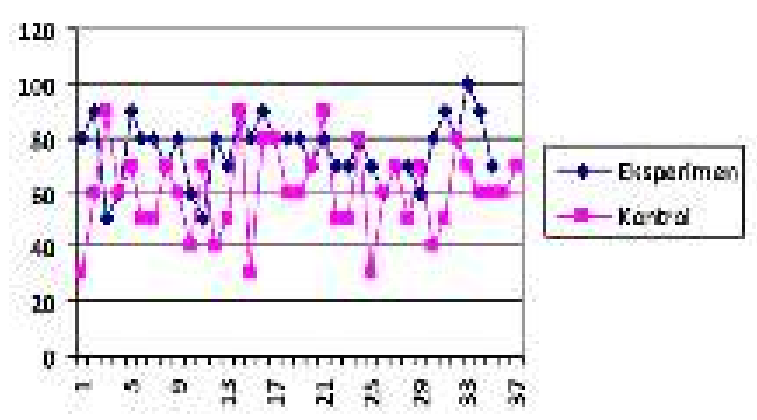

Gambar 6. Hasil Post Tes keterampilan menulis deskripsi siswa pada Kelas Eksperimen dan Kelas Kontrol secara individu

Setelah didapat hasil prates dan pascates keterampilan menulis deskripsi pada kelas eksperimen dan kelas kontrol, selanjutnya dilakukan uji normalitas dan uji homogenitas. Hasilnya didapat seperti dijelaskan tabel 3 dan 4 di bawah ini.

Tabel 3 Hasil Perhitungan Uji Normalitas Data Prates dan Pascates Menggunakan SPSS 20

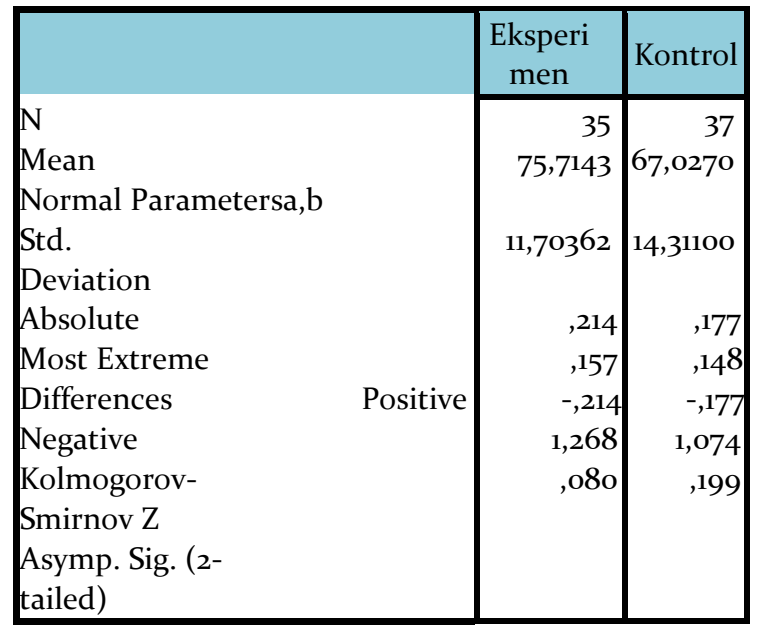

a. Test distribution is Normal.

b. Calculated from data

Melalui data tersebut, maka untuk uji komparasi prates maupun pasca tes keterampilan menulis deskripsi menggunakan uji-t. Hal tersebut dikarenakan data kelas eksperimen berdistribusi normal dan kelas kontrol juga berdistribusi normal. Sehingga data tersebut perlu dilakukan uji homogenitas.

Tabel 4. Hasil Perhitungan Uji Homogenitas Data Prates dan Pascates Menggunakan SPSS 20

Test of Homogeneity of Variances

Nilai

\begin{tabular}{|c|c|c|c|}
\hline $\begin{array}{l}\text { Levene } \\
\text { Statistic }\end{array}$ & $\mathrm{df}_{1}$ & $\mathrm{df}_{2}$ & Sig. \\
\hline ,472 & 1 & 70 & 494 \\
\hline
\end{tabular}

Setelah dilakukan uji normalitas dan uji homogenitas terhadap data prates dan pascates keterampilan menulis deskripsi siswa pada kelas eksperimen dan kontrol, langkah selanjutnya adalah melakukan uji perbedaan menggunakan Analisis Independent Samples T Test.

Tabel 5 Uji t Data Prates dan Pascates keterampilan menulis deskripsi Kelas Eksperimen dan Kontrol

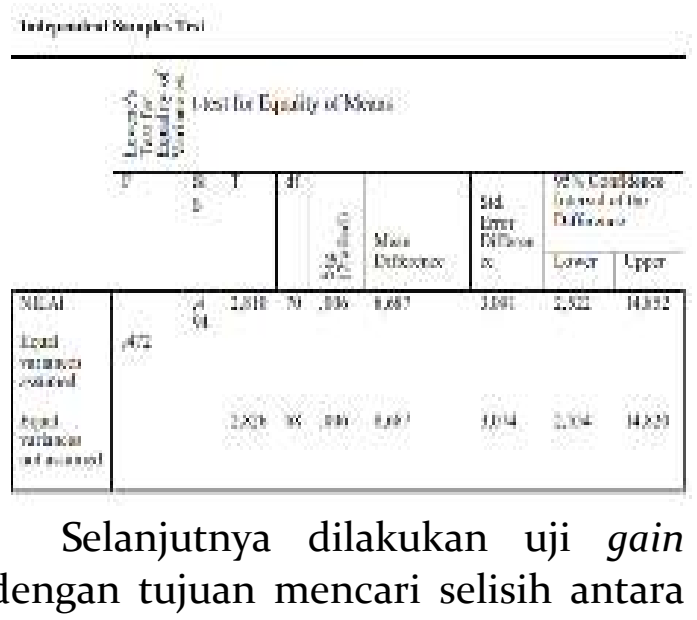


nilai posttest dan prates. Hasilnya dapat dilihat pada tabel di bawah ini.

Tabel 6 Hasil Uji Gain keterampilan menulis deskripsi siswa kelas eksperimen dan kelas kontrol

\begin{tabular}{|c|c|c|c|c|}
\hline \multirow[b]{2}{*}{ Kelas } & \multirow{2}{*}{$\begin{array}{c}\text { Keterampilan } \\
\text { menulis } \\
\text { deskripsi }\end{array}$} & \multicolumn{2}{|c|}{ Skor } & \multirow[b]{2}{*}{ Kriteria } \\
\hline & & $\begin{array}{l}\text { Rata- } \\
\text { rata }\end{array}$ & $\begin{array}{c}\mathrm{N}- \\
\text { gain }\end{array}$ & \\
\hline \multirow{2}{*}{$\begin{array}{l}\text { Eksperi } \\
\text { men }\end{array}$} & Prates & 51,43 & \multirow{2}{*}{0,46} & \multirow{2}{*}{$\begin{array}{l}\text { Eksperim } \\
\text { en }\end{array}$} \\
\hline & Pascates & 75,71 & & \\
\hline \multirow{2}{*}{ Kontrol } & Prates & 46,76 & \multirow{2}{*}{0,28} & \multirow{2}{*}{ Kontrol } \\
\hline & Pascates & 60,68 & & \\
\hline
\end{tabular}

Berdasarkan tabel diatas dapat diinterpretasikan bahwa skor rata-rata prates keterampilan menulis deskripsi siswa pada kelas eksperimen sebesar 51,43 dan hasil pascates sebesar 75,71. Dari data tersebut diperoleh $\mathrm{N}$-gain sebesar o,46. Maka N-gain pada kelas eksperimen termasuk kedalam kriteria "Sedang". Pada kelas kontrol dapat dilihat bahwa skor rata-rata keterampilan menulis deskripsi siswa sebesar 46,76 dan skor pascates sebesar 6o,68. Sehingga diperoleh $\mathrm{N}$-gain sebesar 0,28 Maka dapat disimpulkan bahwa N-gain pada kelas kontrol termasuk ke dalam kriteria "Rendah".

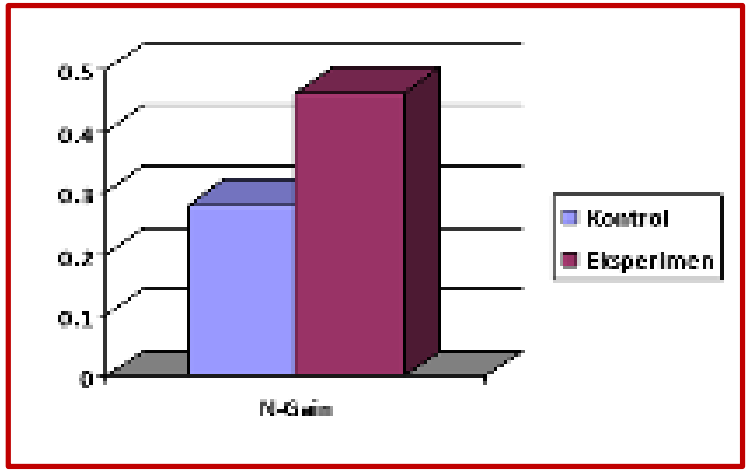

Gambar 7. Hasil Uji Gain keterampilan menulis deskripsi siswa pada kelas eksperimen dan kontrol

Untuk melihat gambaran hasil uji gain keterampilan menulis deskripsi siswa antara kelas eksperimen dengan kelas kontrol secara individu dapat dilihat pada grafik berikut ini.

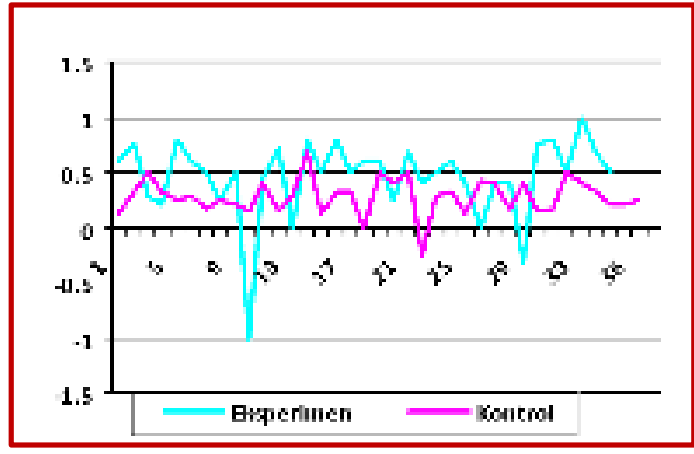

Gambar 8.Hasil Uji Gain keterampilan menulis deskripsi siswa pada kelas eksperimen dan kontrol secara individu

Berdasarkan hasil analisis data dapat diketahui bahwa bahan ajar berbasis kearifan lokal dan budaya efektif dalam meningkatkan keterampilan menulis deskripsi. Peningkatan tersebut terlihat dari nilai pretes dan postes kelas eksperimen. Selain itu mutu peningkatan juga dapat ditunjukkan dari nilai gain.

Bahan ajar yang dibuat dapat digunakan sebagai bersama-sama dengan buku siswa sebagai penunjang pembelajaran. Sejalan dengan itu, Purnomo (2016) juga memaparkan bahwa buku guru dan buku siswa mempunyai fungsi yang penting dalam proses pembelajaran, sebagai pegangan baik guru maupun peserta didik sebagai petunjuk dan sebagai acuan kegiatan proses pembelajaran di kelas.

Pengembangan bahan ajar membuat siswa terlatih untuk memecahkan masalah dan membangun sendiri pengetahuannya (Sutarna, 2019). Hal ini sejalan dengan teori Piaget (Ruseffendi, E.T, 2006) bahwa pembelajaran sebagai proses yang aktif artinya pengetahuan baru tidak diberikan kepada siswa dalam 
bentuk jadi tetapi siswa membentuk sendiri pengetahuannya.

\section{SIMPULAN}

Sesuai dengan tahapan pelaksanaan kegiatan penelitian, maka peneliti dapat mengambil kesimpulan sebagai berikut.

Terdapat peningkatan keterampilan menulis deskripsi siswa yang menggunakan bahan ajar berbasis kearifan lokal dan budaya dibandingkan dengan siswa yang menggunakan pembelajaran konvensional. Peningkatan ini terlihat dari deskripsi data hasil pretest kelas kontrol dan eksperimen, juga deskripsi data hasil postes kelas kontrol dan eksperimen.

Terdapat perbedaan peningkatan keterampilan menulis deskripsi siswa yang menggunakan bahan ajar berbasis berbasis kearifan lokal dan budaya jika dibandingkan dengan siswa yang tidak menggunakan bahan ajar dan dengan pembelajaran konvensional. Perbedaan peningkatan ini dapat dilihat pada hasil uji gain keterampilan menulis deskripsi siswa pada kelas eksperimen menunjukkan $\mathrm{N}$-gain sebesar o,46. Maka $\mathrm{N}$-gain pada kelas eksperimen termasuk ke dalam kriteria "Sedang". Sedangkan hasil uji gain keterampilan menulis deskripsi siswa pada kelas kontrol diperoleh N-gain sebesar o,28. Maka Ngain pada kelas kontrol termasuk ke dalam kriteria "Rendah".

\section{E. SARAN}

Berdasarkan rangkaian kegiatan penelitian yang telah dilaksanakan, peneliti mengemukakan saran sebagai berikut.

Bahan ajar berbasis kearifan lokal dan budaya, Kuningan: Kota Kuda Sejuta Cerita pengembangan bahan ajar dan model pembelajaran yang dapat digunakan oleh guru kelas untuk meningkatkan keterampilan menulis deskripsi pada siswa kelas IV di Kabupaten Kuningan.

Bahan ajar berbasis berbasis kearifan lokal dan budaya pada penelitian ini menunjukkan hasil yang efektif karena digunakan dalam pembelajaran yang mendukung untuk digunakannya bahan ajar. Bagi peneliti selanjutnya, dapat mengkaji kembali keefektifan bahan ajar berbasis berbasis kearifan lokal dan budaya dalam aspek keterampilan atau kemampuan lain dengan lebih luas dan lebih mendalam.

\section{F. UCAPAN TERIMA KASIH}

Ucapan Terima Kasih Terima kasih kepada DRPM Kemenristek/BRIN yang telah memberikan hibah melalui skema Penelitian Dosen Pemula (PDP) pendanaan tahun 2020 sehingga memudahkan penyusunan karya tulis ilmiah ini sebagai salah satu luaran penelitian, Segenap unsur pimpinan STKIP Muhammadiyah Kuningan, para pihak yang telah membantu penulisan karya tulis ilmiah ini dan juga reviewer serta editor jurnal, sehingga kami dapat mempublikasikan topik ini.

\section{DAFTAR PUSTAKA}

Abidin, Yunus. 2013. Guru dan Pembelajaran Bermutu. Bandung: Rizki Press.

Abidin, Yunus. 2013. Pembelajaran Bahasa Berbasis Pendidikan Karakter. Bandung: Refika Aditama

Alfianto. 2008. Pelajaran Bahasa Indonesia untuk Sekolah Dasar. Diakses dari http://id.forum.wordpress.com/t opic/pelajaran-bahasaindonesia.co.id

Alfieri, L., Brooks, P.J., \& Aldrich. N.J. 2009. Does discovery based 
instruction enhance learning. Scholarly Journal, (5), 1-40.

Ary, D., Jacobs, L. C \& Sorensen, C. K. 2010. Introduction to research in education eighth edition. Wadsworth: Cengage Learning.

Cresswell, J. W. 2012. Educational research: Planning, conducting, and evaluating quantitative and qualitative research 4 th edition. Boston: Pearson Education Inc.

Iskandarwassid dan Sunendar 2011. Strategi Pembelajaran Bahasa. Bandung: PT Remaja Rosdakarya.

Kozulin, A., Gindis, B., Ageyew, V.S, \& Miller, S.M. 2003. Vygotsky's educational theory in cultural context. New York: Cambridge University Press.

Linse, T Caroline. 2005. Practical English Language Teaching: Young Learners. New York: McGraw-Hill Companies, Inc.

Meinbach, A.M, Rothelin, L. \& Fredericks, A.D. 2005. The complete guide to thematic unit creating the integrated curriculum. Washington: ChristoperGordin Publishers Inc.

Mulyasa. 2012. Manajemen Pendidikan Karakter. Jakarta: PT. Bumi Aksara

Perwitasari, Suci dkk. 2018. Pengembangan Bahan Ajar Tematik Berbasis Kontekstual. Jurnal Pendidikan: Teori, Penelitian, dan Pengembangan Universitas Negeri Malang Volume: 3 Nomor: 3 Bulan Maret Tahun 2018 Halaman: 278285.

Purnomo, H. \& Wilujeng, I. 2016. Pengembangan bahan ajar dan instrumen penilaian IPA tema Indahnya Negeriku penyempurnaan buku guru dan siswa kurikulum 2013. Jurnal Prima Edukasia, 4 (1), 67-78.
Russeffendi, E.T. 2006. Dasar-dasar Penelitian Pendidikan dan Bidang Non-Eksakta Lainnya. Bandung : Tarsito.

Shufa, Naela Khusna Faela. 2018. Pembelajaran Berbasis Kearifan Lokal Di Sekolah Dasar: Sebuah Kerangka Konseptual. Inopendas Jurnal Ilmiah Kependidikan ISSN 2615-5443 Vol. 1 No. 1, Februari 2018 Hal. 48-53

Sugiyono. 2010. Metode Penelitian Pendidikan. Bandung: Alfabeta

Sutarna, Nana. 2019. Bahan Ajar Berbasis Model Quantum Teaching untuk Meningkatkan Kemampuan Berpikir Kritis. Naturalistic: Jurnal Kajian Penelitian dan Pendidikan dan Pembelajaran Vol.4, No.1 (Oktober 2019): 417-425.

Tinja, Yasintus. dkk. 2017. Pengembangan Bahan Ajar Tematik Berbasis Kearifan Lokal sebagai Upaya Melestarikan Nilai Budaya pada Siswa Sekolah Dasar. Jurnal Pendidikan: Teori, Penelitian, dan Pengembangan Volume: 2 Nomor: 9 Bulan September Tahun 2017.

Wibowo, Roni. dkk. 2017. Bahan Ajar Tematik Materi Puisi Kelas V SD dengan Pemanfaatan Peta Pikiran dan Lingkungan Sekitar. Jurnal Pendidikan: Teori, Penelitian, dan Pengembangan Volume: 2 Nomor: 6 Bulan Juni Tahun 2017. 